\title{
Response of young pigs to feeding potato protein and potato fibre - nutritional, physiological and biochemical parameters
}

\author{
A. Tuśnioํㅜ, B. Pastuszewska, E. Święch and M. Taciak \\ The Kielanowski Institute of Animal Physiology and Nutrition, Polish Academy of Sciences \\ 05-110 Jabtonna, Poland
}

(Received 2 February 2011; revised version 7 July 2011; accepted 9 August 2011)

\begin{abstract}
Two experiments were performed on growing pigs to determine the effects of potato protein and potato fibre on growth performance, apparent ileal and total tract digestibility, digesta transit time, blood biochemical parameters and small intestinal morphology. Apparent ileal digestibility (AID) of potato protein concentrate and most essential amino acids was significantly lower than that of casein. The substitution of potato fibre for cellulose did not affect significantly AID. Potato fibre tended to reduce the utilization of protein ingested. Passage rate of digesta was affected mostly by the type of fibre. Dietary protein and fibre did not influence the relative weight of stomach and jejunum whereas their effects on other segments were variable. Morphological parameters were affected either by protein and by fibre but course and magnitude of these effects were inconsistent and differed among the segments. In most cases interactive effects of both factors were found. Potato fibre did not reveal beneficial health effects on lipid metabolism.
\end{abstract}

KEY WORDS: pigs, potato protein concentrate, potato fibre preparation, apparent ileal digestibility, intestinal morphology, biochemical parameters

\section{INTRODUCTION}

Potato protein and potato fibre preparations are the refined by-products of the potato starch industry and are putative components of animal feeds and human diets.

Potato protein concentrate (PPC) is considered as a valuable source of essential amino acids which can replace animal protein in piglet diets (Kerr et al., 1998;

\footnotetext{
${ }^{1}$ Corresponding author: e-mail: a.tusnio@ifzz.pan.pl
} 
Sardi et al., 2005). According to Kerr et al. (1998), piglets fed PPC at 3 to 5\% of the diet had satisfactory growth performance but greater additions seemed to decrease feed intake and growth rate. The negative effects of PPC have been attributed to solanidine glycoalkaloids (GA) since weanling piglets tolerated greater amounts of PPC with low than with high GA concentration. The GA content in PPC produced in standard industrial conditions may vary from 927 to $2632 \mathrm{mg} / \mathrm{kg}$ (Pastuszewska et al., 2009) while it is considerably lower (about $150 \mathrm{mg} / \mathrm{kg}$ ) in a low-glycoalkaloid PPC, produced using special technology (Kerr et al., 1998; Refstie and Tiekstra, 2003). Another antinutritional factor in PPC are inhibitors of proteolytic enzymes (TI) whose activity may range from 0.97 to $3.70 \mathrm{mg} / \mathrm{g}$ (Pastuszewska et al., 2009). The effects of potato TI in rats are reported to be similar to those present in soya (Lee et al., 1985). Both antinutrients operate in the digestive tract and may influence digestibility of potato protein concentrate and morphology of the gut in young pigs, as it was found in chicken (Tuśnio et al., submitted to publication).

Potato fibre (PF) preparations have been examined as a potential source of functional dietary fibre for feed and food purposes. The PF preparations contain 5 to $7 \%$ of crude protein, 20 to $24 \%$ of crude fibre, 26 to $30 \%$ of ADF, 45 to $47 \%$ of NDF and about 10\% of starch (Jakob et al., 1999; Antuszewicz, 2006; Serena and Bach Knudsen, 2007). Dietary fibre contributes to over $60 \%$ of PF dry matter and its main components are cellulose, hemicellulose and pectins. Potato fibre, particularly its soluble fraction, is highly fermentable and stimulates microbial production of SCFA both in rats and pigs (Antuszewicz, 2005a; Lærke et al., 2007). Very limited and equivocal data are available on the effects of PF on nutrient digestibility and on parameters related to lipid and glucose metabolism (Jakob et al., 1999; Antuszewicz 2005b; Lærke et al., 2007). Potato fibre was reported to have trophic effect on relative weight of stomach and small intestine in rats without modification of duodenal histology (Antuszewicz, 2006). No such observations are available for young pigs.

Dietary protein and fibre have great impact on the functional status of gastrointestinal tract and, consequently, on immunology, health and performance of young pigs. In view of the paucity of data on the effects of feeding respective potato products, the study was undertaken to assess the response of young pigs to diet with a high content of PPC and PF in terms of growth performance and selected nutritional, physiological and biochemical parameters. The main objective of the study was to find out whether potato protein can be safety fed to pigs at relatively high dietary level, and whether potato fibre may be considered as a beneficial dietary supplement. 


\section{MATERIAL AND METHODS}

\section{Experimental design}

Two experiments were performed. In Experiment 1, apparent ileal digestibility (AID) of protein and amino acids of casein (CAS) and potato protein concentrate (PPC) was determined and the effect of potato fibre (PF) on the apparent ileal protein and amino acids digestibility of the mixture of PPC and CAS was estimated and compared with that of cellulose (CEL). In Experiment 2, the effects of supplementing cereal diets with casein or potato protein and with CEL or PF, were determined in a two-factorial design. Growth performance, nutrients digestibility, $\mathrm{N}$-balance and energy utilization, and transit time of digesta were determined in vivo, and post-mortem weight of digestive organs, viscosity of digesta, morphometry of small intestine and selected biochemical blood parameters were measured. The experiments was approved by the Local Animal Care Commission.

\section{Diets}

The commercial potato protein concentrate was purchased from Trouw Nutrition Company and food grade casein from Milk Cooperative Mlekpol (Poland). Potato fibre preparation (produced by Lyckeby Starkelsen, Sweden) was furnished by Culinar Comp. (Poland), and cellulose Arbocel was supplied by Rettenmaier Comp. (Germany). The glycoalkaloids (GA) concentration in PPC was $677 \mathrm{mg} /$ $\mathrm{kg}$ and trypsin inhibitor activity (TI) $3.91 \mathrm{mg} / \mathrm{g}$.

In Experiment 1, three semipurified diets were prepared. The diets contained either CAS (diet 1) or CAS and PPC in proportion of protein 1:1 (diets 2 and 3) and were supplemented either with CEL (diets 1 and 2) or PF (diet 3) (Table 1). The diets contained chromic oxide as a marker.

In Experiment 2, four cereal-based diets contained as the main source of protein either casein (diets 1 and 2) or potato protein concentrate (diets 3 and 4) and were supplemented either with CEL (diets 1 and 3) or PF (diets 2 and 4) (Table 2). The diets were supplemented with crystalline amino acids (AA) to cover the require according to Rademacher et al. (1999).

\section{Animals and experimental procedures}

Experiment 1 was carried out on 6 barrows, of synthetic line 990, at $21 \mathrm{~kg}$ (SEM=0.69) of initial body weight (BW) according to a cross-over design. The animals were surgically fitted with a post-valvular T-caecum cannula (PVTC) 
Table 1. Composition of diets, Experiment 1

\begin{tabular}{|c|c|c|c|}
\hline \multirow{2}{*}{ Item } & \multicolumn{3}{|c|}{ Diets } \\
\hline & 1 & 2 & 3 \\
\hline \multicolumn{4}{|l|}{ Ingredients, $\mathrm{g} / \mathrm{kg}$} \\
\hline casein & 225.0 & 112.5 & 112.5 \\
\hline $\mathrm{PPC}^{1}$ & - & 123.5 & 123.5 \\
\hline soyabean oil & 15.0 & 15.0 & 15.0 \\
\hline sugar & 100.0 & 100.0 & 100.0 \\
\hline vitamin-mineral mixture ${ }^{2}$ & 5.8 & 5.8 & 5.8 \\
\hline $\mathrm{NaCl}$ & 3.0 & 3.0 & 3.0 \\
\hline dicalcium phosphate & 15.0 & 15.0 & 15.0 \\
\hline limestone & 6.0 & 7.0 & 7.0 \\
\hline maize starch & 567.2 & 555.2 & 555.2 \\
\hline cellulose & 60.0 & 60.0 & - \\
\hline potato fibre preparation & - & - & 60.0 \\
\hline $\mathrm{Cr}_{2} \mathrm{O}_{3}$ & 3.0 & 3.0 & 3.0 \\
\hline \multicolumn{4}{|l|}{ Calculated analysis } \\
\hline $\mathrm{ME}, \mathrm{MJ} / \mathrm{kg}$ & 15.7 & 15.5 & 15.5 \\
\hline crude protein ${ }^{3}$ & 177.5 & 177.5 & 180.0 \\
\hline glycoalkaloids, mg/kg diet ${ }^{4}$ & - & 83.6 & 83.6 \\
\hline trypsin inhibitor, $\mathrm{mg} / \mathrm{g}$ diet $^{5}$ & - & 0.48 & 0.58 \\
\hline
\end{tabular}

${ }^{1}$ PPC - potato protein concentrate; ${ }^{2}$ provided per kg of diet: IU: vit. A 15000 ; vit. $\mathrm{D}_{3} 2$ 000; mg: vit. E 60 ; vit. $\mathrm{B}_{1} 1$; vit. $\mathrm{B}_{2} 4$; biotine 0.25 ; vit. $\mathrm{B}_{6} 3$; vit. $\mathrm{B}_{12} 0.02$; vit. $\mathrm{K} 3$; niacine 20; folic acid 5; Ca pantotenate 15; choline chloride 150; Mg 150; Mn 50; Zn 150; Co 0.5; Se 0.3; Cu 150; Fe 125; I 1; g: Ca $1.3 ;{ }^{3}$ analysed results; ${ }^{4}$ solanidine glycoalkaloids provide by PPC; ${ }^{5}$ trypsin inhibitor activity provide by PPC and potato fibre preparation

according to van Leeuwen et al. (1991) and kept in metabolic cages with free access to water, in a room with controlled temperature at $23^{\circ} \mathrm{C}$. After recovery, the animals were fed experimental diets during seven days and during last three days digesta was collected during $12 \mathrm{~h}$. The pigs were fed twice a day at 8.00 and 20.00 $\mathrm{h}$ with equal portions of meal diets mixed with water (1:1). Digesta collected from each pig was immediately frozen at $-18^{\circ} \mathrm{C}$, and after completion of the experiment the pooled samples each representing one of six animals per diet, were taken, freeze-dried and analysed for chromium oxide, nitrogen and amino acids.

In Experiment 2 four groups of 6 barrows of synthetic line 990 and mean initial BW $15 \mathrm{~kg}(\mathrm{SEM}=0.41)$ were maintained in metabolic cages and fed during 21 days on experimental diets. Feeding level ranged about $5 \%$ body weight. N-balance experiment comprised $7 \mathrm{~d}$ of preliminary period followed by 6 days of total collection of faeces and urine. Measurement of transit time was done during $104 \mathrm{~h}$. Collection of faeces started $6 \mathrm{~h}$ after feeding single portions of the experimental diets supplemented with chromic oxide. During first $56 \mathrm{~h}$ faeces were collected every $30 \mathrm{~min}$ and next at four-hour intervals. Number of voided portions, weight of fresh and dry matter of faeces, and recovery of the marker were calculated. 
Table 2. Composition of diets, Experiment 2

\begin{tabular}{|c|c|c|c|c|}
\hline \multirow{2}{*}{ Item } & \multicolumn{2}{|c|}{ Casein } & \multicolumn{2}{|c|}{$\mathrm{PPC}^{5}$} \\
\hline & $\mathrm{CEL}^{6}$ & $\mathrm{PF}^{7}$ & CEL & $\mathrm{PF}$ \\
\hline \multicolumn{5}{|l|}{ Ingredients, $\mathrm{g} / \mathrm{kg}$} \\
\hline wheat & 430.0 & 430.0 & 430.0 & 430.0 \\
\hline maize & 150.0 & 150.0 & 150.0 & 150.0 \\
\hline full-fat soyabean & 60.0 & 60.0 & 60.0 & 60.0 \\
\hline casein & 127.5 & 127.5 & - & - \\
\hline PPC & - & - & 175.0 & 175.0 \\
\hline cellulose & 60.0 & - & 60.0 & - \\
\hline potato fibre preparation & - & 60.0 & - & 60.0 \\
\hline sugar & 25.0 & 25.0 & 25.0 & 25.0 \\
\hline soyabean oil & 22.0 & 22.0 & 45.0 & 45.0 \\
\hline limestone & 8.0 & 8.0 & 8.0 & 8.0 \\
\hline $\mathrm{NaCl}$ & 3.5 & 3.5 & 3.5 & 3.5 \\
\hline vitamin-mineral mixture $^{1}$ & 5.8 & 5.8 & 5.8 & 5.8 \\
\hline dicalcium phosphate & 25.0 & 25.0 & 25.0 & 25.0 \\
\hline maize starch & 81.6 & 81.6 & 10.3 & 10.3 \\
\hline L-lysine $\mathrm{HCl}(78 \%)$ & - & - & 1.6 & 1.6 \\
\hline L-threonine $(98 \%)$ & 1.6 & 1.6 & - & - \\
\hline L-methionine (98\%) & - & - & 0.5 & 0.5 \\
\hline L-tryptophan $(98 \%)$ & - & - & 0.3 & 0.3 \\
\hline \multicolumn{5}{|l|}{ Calculated analysis } \\
\hline $\mathrm{ME}, \mathrm{MJ} / \mathrm{kg}$ & 13.8 & 13.8 & 13.8 & 13.8 \\
\hline crude protein ${ }^{2}$ & 186.0 & 191.0 & 220.0 & 215.0 \\
\hline glycoalkaloids, $\mathrm{mg} / \mathrm{kg} \operatorname{diet}^{3}$ & - & - & 118.5 & 118.5 \\
\hline trypsin inhibitor, $\mathrm{mg} / \mathrm{g}$ diet $^{4}$ & _ & - & 0.68 & 0.78 \\
\hline
\end{tabular}

${ }^{1}$ provided per kg of diet: IU: vit. A 15 000; vit. $\mathrm{D}_{3} 2000$; mg: vit. E 60; vit. $\mathrm{B}_{1} 1$; vit. $\mathrm{B}_{2} 4$; biotine 0.25 ; vit. $\mathrm{B}_{6} 3$; vit. $\mathrm{B}_{12} 0.02$; vit. $\mathrm{K} 3$; niacine 20; folic acid 5; Ca pantotenate 15 ; choline chloride 150; Mg 150; Mn 50; Zn 150; Co 0.5; Se 0.3; Cu 150; Fe 125; I 1; g: Ca 1.3; ${ }^{2}$ analysed results; ${ }^{3}$ solanidine glycoalkaloids provide by PPC; ${ }^{4}$ trypsin inhibitor activity provide by PPC and potato fibre preparation; ${ }^{5}$ potato protein concentrate; ${ }^{6}$ cellulose; ${ }^{7}$ potato fibre preparation

At the end of the experiment, the animals were sacrificed and mixed blood was collected to heparinized tubes, centrifuged at $6000 \mathrm{~g}$ for $10 \mathrm{~min}$ at $4^{\circ} \mathrm{C}$ and plasma stored at $-18^{\circ} \mathrm{C}$ till analysis. Digestive tract was dissected and ileal digesta was sampled and viscosity was determined. Stomach, small intestine, liver and pancreas were weighed and samples of duodenum, mid jejunum and ileum were taken and preserved for histological examination.

\section{Analytical methods and morphometry}

Dry matter, total nitrogen, ether extract, crude fibre, crude ash in the diets, ileal digesta and faeces were estimated according to AOAC (1990). Gross energy content in diets and faeces was determined using a Parr adiabatic oxygen bomb calorimeter (KL-11). Chromic oxide was determined according to Kimura and Miller (1957). 
Amino acid analyses were performed with the Beckman high pressure AA analyzer System Gold (Beckman Instruments, Inc. Fullerton, CA, USA) after acid hydrolysis, methionine and cystine after oxidation with performic acid, and tryptophan after hydrolysis with barium hydroxide (Buraczewska and Buraczewski, 1984).

Total glycoalkaloids content (solanine and chaconine) in potato protein concentrate was analysed as described by Bergers (1980), and TI was determined using the method of Kakade et al. (1974) and expressed as mg of pure trypsin inactivated by $1 \mathrm{~g}$ of PPC.

Samples of ileal digesta were centrifuged at $10000 \mathrm{~g}$ for $10 \mathrm{~min}$ at $4^{\circ} \mathrm{C}$. The viscosity of supernatant $(0.5 \mathrm{ml}$ aliquot $)$ was immediately measured with the use of Brookfield Digital cone/plate viscometer (model LVDV II+, Brookfield Engineering Laboratories, Stoughton, MA, USA). Readings were expressed in $\mathrm{mPa} \cdot \mathrm{s}$.

For determination of biochemical indices the analysis was performed using an Ectachem DT60 Analyser (Eastman Kodak, Rochester, NY, USA).

Segments of duodenum, mid jejunum and ileum were fixed in Bouin solution for four days, dehydrated and embedded in paraffin wax. Serial sections of $5 \mu \mathrm{m}$ thickness were cut with rotary microtome (Microm 350, Germany), mounted on slides, stained with haematoxylin and counter-stained with eosin. The slides were examined under a light microscope (Zeiss Axio Star Plus) coupled with a camera (Canon, Power Shot A620) to a computer. Villus height (from tip to crypt mouth), crypt depth (from crypt mouth to base), width of tunica muscularis and tunica mucosa were measured (in the Axio Vision LE Rel 4.5). Averages for each parameter represent 30 measurements per segment.

\section{Calculations and statistics}

Apparent ileal digestibility (AID) of protein and amino acids was calculated from chromium oxide content in diets and digesta using equations given by Buraczewska et al. (1999). Apparent ileal digestibility of potato protein was calculated by difference method between diet 1 and 2 in Experiment 1 . Metabolizable energy values of diets were calculated as a sum of the energy of dietary components. The results of Experiment 1 were subjected to one-way ANOVA while results of Experiment 2 to two-factorial ANOVA procedures. Differences among groups were evaluated using Tukey test. 


\section{RESULTS}

\section{Chemical composition of potato protein concentrate}

The chemical and essential amino acids composition of PPC used in Experiments 1 and 2 is presented in Table 3. Potato protein concentrate contained about $814 \mathrm{~g} / \mathrm{kg}$ crude protein and trace amounts of fibre. Concentration of GA was $677 \mathrm{mg} / \mathrm{kg}$ and of TI $3.9 \mathrm{mg} / \mathrm{g}$.

Table 3. Composition of potato protein concentrate

\begin{tabular}{lr}
\hline Item & $\mathrm{PPC}^{1}$ \\
\hline Dry matter, \% & 91.78 \\
Crude protein $(\mathrm{N} \times 6.25), \% \mathrm{DM}$ & 81.44 \\
Ether extract, \% DM & 1.47 \\
Esh, \% DM & 2.66 \\
Crude fibre, \% DM & 0.79 \\
Starch, \% DM & 7.27 \\
Glycoalkaloids, $\mathrm{mg} / \mathrm{kg}^{2}$ & 677.00 \\
Trypsin inhibitor, $\mathrm{mg} / \mathrm{g}^{3}$ & 3.91 \\
& \\
Essential amino acids, $\mathrm{g} 16 / \mathrm{g} N$ & \\
$\quad$ lysine & 7.67 \\
$\quad$ methionine & 2.14 \\
$\quad$ cystine & 1.52 \\
methionine + cystine & 3.66 \\
threonine & 5.63 \\
tryptophan & 1.69 \\
phenylalanine & 6.46 \\
tyrosine & 5.26 \\
valine & 6.77 \\
isoleucine & 5.53 \\
leucine & 10.24 \\
histidine & 2.06 \\
\hline
\end{tabular}

${ }^{1}$ potato protein concentrate; ${ }^{2}$ solanidine glycoalkaloids; ${ }^{3}$ trypsin inhibitor activity

\section{Apparent ileal digestibility of protein and amino acids (Experiment 1)}

The results shown in Table 4 represent the protein and amino acid AID values of casein fed as the only protein source (diet 1) and PPC (calculated by difference method between diets 1 and 2), both fed with CEL, and values for the mixture of CAS and PPC fed either with CEL or with PF (diets 2 and 3, respectively). Apparent ileal protein digestibility of PPC was 11 units lower than of casein. Among indispensable amino acids only AID of isoleucine did not differ while the greatest difference was found for cystine ( $33.1 \mathrm{vs} 65.7 \%$ for potato protein and casein, respectively). Apparent ileal digestibility of dispensable amino acids 
Table 4. Apparent ileal digestibility of protein and amino acids (\%), initial body weight of pigs $21 \mathrm{~kg}$ (Experiment 1)

\begin{tabular}{|c|c|c|c|c|c|c|}
\hline \multirow{3}{*}{$\frac{\text { Dietary components }}{\text { Protein }}$} & \multicolumn{6}{|c|}{ Diet } \\
\hline & \multicolumn{2}{|c|}{1} & \multirow{3}{*}{ SEM $^{5}$} & 2 & 3 & \multirow{3}{*}{$\mathrm{SEM}^{6}$} \\
\hline & $\mathrm{CAS}^{1}$ & $\mathrm{PPC}^{2}$ & & $\mathrm{CAS}+\mathrm{PPC}$ & $\mathrm{CAS}+\mathrm{PPC}$ & \\
\hline Fibre & $\mathrm{CEL}^{3}$ & CEL & & CEL & $\mathrm{PF}^{4}$ & \\
\hline Protein & $88.2^{\mathrm{b}}$ & $76.9^{\mathrm{a}}$ & 1.31 & 82.6 & 80.5 & 1.00 \\
\hline \multicolumn{7}{|l|}{ Amino acids } \\
\hline lysine & $96.4^{b}$ & $83.0^{\mathrm{a}}$ & 1.54 & 89.6 & 90.6 & 0.73 \\
\hline methionine & $95.2^{\mathrm{b}}$ & $88.0^{\mathrm{a}}$ & 0.36 & 91.6 & 91.5 & 0.42 \\
\hline cystine & $65.7^{b}$ & $33.1^{\mathrm{a}}$ & 3.90 & 49.3 & 47.5 & 2.11 \\
\hline threonine & $87.9^{b}$ & $78.9^{\mathrm{a}}$ & 1.87 & $83.6^{\mathrm{b}}$ & $79.0^{\mathrm{a}}$ & 1.15 \\
\hline tryptophan & $91.9^{\mathrm{b}}$ & $65.9^{\mathrm{a}}$ & 1.14 & 78.8 & 78.1 & 1.43 \\
\hline phenylalanine & $95.4^{\mathrm{b}}$ & $82.9^{\mathrm{a}}$ & 1.29 & 89.0 & 88.0 & 0.80 \\
\hline tyrosine & $95.6^{\mathrm{b}}$ & $81.9^{\mathrm{a}}$ & 1.19 & 88.7 & 87.5 & 0.78 \\
\hline valine & $90.7^{b}$ & $84.3^{\mathrm{a}}$ & 0.80 & $87.4^{\mathrm{b}}$ & $85.0^{\mathrm{a}}$ & 0.77 \\
\hline isoleucine & 84.8 & 83.0 & 1.58 & $83.9^{\mathrm{b}}$ & $80.2^{\mathrm{a}}$ & 1.01 \\
\hline leucine & $94.7^{b}$ & $83.6^{\mathrm{a}}$ & 1.26 & 89.0 & 88.1 & 0.77 \\
\hline histidine & $95.4^{\mathrm{b}}$ & $81.6^{\mathrm{a}}$ & 1.17 & 88.5 & 87.6 & 0.66 \\
\hline
\end{tabular}

${ }^{1}$ casein; ${ }^{2}$ potato protein concentrate, calculated from difference between diet 1 and $2 ;{ }^{3}$ cellulose $;{ }^{4}$ potato fibre preparation; ${ }^{5}$ calculated for CAS/CEL and PPC/CEL diet; ${ }^{6}$ calculated for CAS+PPC/CEL and $\mathrm{CAS}+\mathrm{PPC} / \mathrm{PF}$ diet; ${ }^{\mathrm{a}, \mathrm{b}}$ means in the column with differentsuperscriptsaresignificantly different $(\mathrm{P}<0.05)$

differed to smaller extent and in case of serine and glycine was even greater for potato protein (data not shown). The substitution of PF for CEL (diet 3 vs 2) did not affect significantly AID of protein and majority of indispensable amino acids except lower values of AID of threonine, valine and isoleucine. Among dispensable amino acids, AID of aspartic acid, serine, and glycine were also lower on PF than on CEL (data not shown).

Growth performance, nutrients digestibility, protein and energy utilization (Experiment 2)

Average daily gain of pigs fed on cereal diets was affected neither by supplementary protein nor fibre while $\mathrm{F} / \mathrm{G}$ ratio tended to be slightly better $(\mathrm{P}=0.07)$ on PPC than on CAS (Table 5).

Table 5. Effects of protein (P) and fibre (F) on growth performance (Experiment 2)

\begin{tabular}{|c|c|c|c|c|c|c|c|c|}
\hline \multirow{2}{*}{ Item } & \multicolumn{2}{|c|}{ Casein } & \multicolumn{2}{|c|}{$\mathrm{PPC}^{1}$} & \multirow{2}{*}{ SEM } & \multicolumn{3}{|c|}{ Significance } \\
\hline & $\mathrm{CEL}^{2}$ & $\mathrm{PF}^{3}$ & CEL & $\mathrm{PF}$ & & $\mathrm{P}$ & $\mathrm{F}$ & $\mathrm{P} \times \mathrm{F}$ \\
\hline Initial body weight, $\mathrm{kg}$ & 15.2 & 15.0 & 14.8 & 15.3 & 0.41 & & & \\
\hline $\mathrm{ADG}^{4}, \mathrm{~kg}$ & 0.67 & 0.66 & 0.68 & 0.67 & 0.02 & 0.59 & 0.59 & 0.66 \\
\hline Body weight gain, $\mathrm{kg}$ & 13.5 & 13.9 & 14.3 & 14.6 & 0.49 & 0.14 & 0.46 & 0.86 \\
\hline $\mathrm{F} / \mathrm{G}^{5}$ ratio & 1.4 & 1.4 & 1.4 & 1.4 & 0.04 & 0.07 & 0.73 & 0.82 \\
\hline
\end{tabular}

${ }^{1}$ potato protein concentrate; ${ }^{2}$ cellulose; ${ }^{3}$ potato fibre preparation; ${ }^{4}$ average daily gain; ${ }^{5}$ feed:gain ratio 
Total protein digestibility of diets supplemented with CAS was significantly higher than with PPC and was not affected by type of fibre (Table 6). On the contrary, $\mathrm{PF}$ tended to reduce the metabolic utilization of protein $(\mathrm{N}$ retained/N absorbed). In consequence, the utilization of protein ingested ( $\mathrm{N}$ retained/ $\mathrm{N}$ intake) tended to be lower $(\mathrm{P}=0.08)$ on diets supplemented with $\mathrm{PF}$ while it did not differ between diets supplemented with casein or potato protein concentrate.

Table 6. Effects of supplementary protein (P) and fibre (F) on nutrients digestibility and protein and energy utilization (Experiment 2)

\begin{tabular}{|c|c|c|c|c|c|c|c|c|}
\hline \multirow{2}{*}{ Item } & \multicolumn{2}{|c|}{ Casein } & \multicolumn{2}{|c|}{$\mathrm{PPC}^{1}$} & \multirow{2}{*}{ SEM } & \multicolumn{3}{|c|}{ Significance } \\
\hline & $\mathrm{CEL}^{2}$ & $\mathrm{PF}^{3}$ & CEL & $\mathrm{PF}$ & & $\mathrm{P}$ & $\mathrm{F}$ & $\mathrm{P} \times \mathrm{F}$ \\
\hline \multicolumn{9}{|l|}{$\overline{\text { Digestibility, \% }}$} \\
\hline protein & 86.67 & 86.11 & 84.52 & 83.80 & 1.02 & 0.05 & 0.57 & 0.90 \\
\hline crude fat & 48.64 & 52.01 & 65.60 & 70.29 & 2.18 & 0.00 & 0.08 & 0.76 \\
\hline crude fibre & 22.79 & 59.24 & 25.58 & 53.72 & 4.37 & 0.76 & 0.00 & 0.35 \\
\hline crude ash & 47.85 & 50.10 & 54.66 & 59.74 & 1.90 & 0.00 & 0.07 & 0.46 \\
\hline $\mathrm{NFE}^{4}$ & 92.47 & 94.02 & 91.50 & 93.53 & 0.33 & 0.04 & 0.00 & 0.47 \\
\hline \multicolumn{9}{|l|}{ Protein utilization, \% } \\
\hline $\mathrm{N}$ retained/ $\mathrm{N}$ absorbed & 70.34 & 66.00 & 71.18 & 65.06 & 2.51 & 0.99 & 0.11 & 0.79 \\
\hline $\mathrm{N}$ retained/ $\mathrm{N}$ intake & 60.80 & 56.81 & 60.19 & 54.31 & 2.69 & 0.57 & 0.08 & 0.73 \\
\hline \multicolumn{9}{|l|}{ Energy utilization, \% } \\
\hline digestibility & 82.85 & 86.49 & 82.41 & 85.73 & 0.67 & 0.39 & 0.00 & 0.82 \\
\hline metabolizability & 78.70 & 82.16 & 78.29 & 81.45 & 0.64 & 0.39 & 0.00 & 0.82 \\
\hline ME content, $\mathrm{MJ} / \mathrm{kg}$ & 14.54 & 15.22 & 15.23 & 15.80 & & & & \\
\hline
\end{tabular}

${ }^{1}$ potato protein concentrate; ${ }^{2}$ cellulose; ${ }^{3}$ potato fibre preparation; ${ }^{4} \mathrm{~N}$-free extractives

The effects of protein and fibre on the digestibility of other nutrients were variable. Digestibility of fat was greater on diets supplemented with potato protein than with casein and with PF greater than with CEL thus being the smallest on diet containing casein and CEL and the greatest on diet containing potato protein and PF (48.6 vs 70.3 , respectively). Digestibility of crude fibre was substantially greater on PF than on CEL (53.7 vs 25.6 and 59.2 vs 22.8 on potato protein and casein diets, respectively). Digestibility of ash was greater on potato protein than on casein diets and greater on PF than on CEL, the positive effect of fibre being more evident when fed with potato protein than with casein (59.7 vs 50.1 and 54.7 vs 47.8 , respectively). Digestibility of $\mathrm{N}$-free extractives depended on the protein and fibre and was significantly greater on diets supplemented with PF.

Digestibility of energy of diets supplemented with PF was about 3 units greater than with CEL while the metabolizability of energy (utilization of energy absorbed) was $95 \%$ and depended on fibre. In consequence, the metabolizable energy content of diets with PF was approximately $0.6 \mathrm{MJ} / \mathrm{kg}$ greater than of diets with CEL. 


\section{Transit time of digesta (Experiment 2)}

Parameters related to the passage rate of digesta were affected mostly by the type of fibre since only the number of voided faecal portions was smaller on potato protein than on casein (Table 7). Feeding PF decreased total excretion of fresh and dry matter and extended time needed for recovery of 5 and $50 \%$ of the marker both on casein and on potato protein diets. Total recovery of the marker ranged from 88 to $91 \%$ and was not affected by the diet.

Table 7. Effects of supplementary protein $(\mathrm{P})$ and fibre $(\mathrm{F})$ on passage rate of digesta

\begin{tabular}{|c|c|c|c|c|c|c|c|c|}
\hline \multirow{2}{*}{ Item } & \multicolumn{2}{|c|}{ Casein } & \multicolumn{2}{|c|}{$\mathrm{PPC}^{1}$} & \multirow{2}{*}{ SEM } & \multicolumn{3}{|c|}{ Significance } \\
\hline & $\mathrm{CEL}^{2}$ & $\mathrm{PF}^{3}$ & CEL & $\mathrm{PF}$ & & $\mathrm{P}$ & $\mathrm{F}$ & $P \times F$ \\
\hline $\begin{array}{l}\text { No of faecal portions } \\
\text { voided }\end{array}$ & 28 & 27 & 25 & 22 & 1.65 & 0.03 & 0.29 & 0.61 \\
\hline $\begin{array}{l}\text { Total fresh weight of } \\
\text { faeces, } \mathrm{kg}\end{array}$ & 2.44 & 2.04 & 2.50 & 1.94 & 0.13 & 0.89 & 0.00 & 0.54 \\
\hline $\begin{array}{l}\text { Total weight of dry } \\
\text { matter of faeces, } \mathrm{kg}\end{array}$ & 789 & 606 & 841 & 591 & 30.37 & 0.50 & 0.00 & 0.29 \\
\hline $\begin{array}{l}\text { Faecal dry matter } \\
\text { content, } \%\end{array}$ & 30.9 & 29.6 & 33.6 & 30.4 & 1.48 & 0.55 & 0.38 & 0.41 \\
\hline $\begin{array}{l}\text { Total recovery of the } \\
\text { matter, } \%\end{array}$ & 88.3 & 87.7 & 91.4 & 87.6 & 2.12 & 0.55 & 0.38 & 0.41 \\
\hline $\begin{array}{l}\text { Time of } 5 \% \text { recovery of } \\
\text { the marker, } h\end{array}$ & 25.9 & 29.9 & 27.0 & 32.8 & 2.60 & 0.47 & 0.08 & 0.73 \\
\hline $\begin{array}{l}\text { Time of } 50 \% \text { recovery } \\
\text { of the marker, } h\end{array}$ & 34.7 & 40.9 & 36.7 & 51.0 & 2.83 & 0.24 & 0.03 & 0.17 \\
\hline
\end{tabular}

${ }^{1}$ potato protein concentrate; ${ }^{2}$ cellulose; ${ }^{3}$ potato fibre preparation

Relative weight of gastro-intestinal tract and organs and viscosity of digesta (Experiment 2)

Dietary protein and fibre did not influence the relative weight of stomach and jejunum whereas their effects on other segments were variable (Table 8). The weight of duodenum was not affected by protein but was reduced in animals fed on diets with PF. On the contrary, the mass of ileum did not depend on fibre but was increased due to feeding potato protein. Feeding both PF and potato protein enhanced mass of pancreas which was the smallest on diet containing casein and $\mathrm{CEL}$ and the greatest on diet containing potato protein and PF (1.6 vs $2.1 \mathrm{~g} / \mathrm{kg}$ $\mathrm{BW}$, respectively). Relative mass of liver was slightly greater in animals fed on potato protein while it was not affected by the type of fibre. 
Table 8. Effects of supplementary protein (P) and fibre (F) on relative weight of segments and organs of the intestinal tract, $\mathrm{g} / \mathrm{kg}$ body weight (Experiment 2 )

\begin{tabular}{|c|c|c|c|c|c|c|c|c|}
\hline \multirow{2}{*}{ Item } & \multicolumn{2}{|c|}{ Casein } & \multicolumn{2}{|c|}{$\mathrm{PPC}^{1}$} & \multirow{2}{*}{ SEM } & \multicolumn{3}{|c|}{ Significance } \\
\hline & $\mathrm{CEL}^{2}$ & $\mathrm{PF}^{3}$ & CEL & PF & & $\mathrm{P}$ & $\mathrm{F}$ & $\mathrm{P} \times \mathrm{F}$ \\
\hline Stomach & 7.8 & 7.8 & 7.9 & 7.3 & 0.29 & 0.55 & 0.26 & 0.39 \\
\hline Duodenum & 1.5 & 1.26 & 1.5 & 1.3 & 0.09 & 0.61 & 0.02 & 0.78 \\
\hline Jejunum & 32.4 & 32.6 & 35.2 & 32.9 & 0.91 & 0.11 & 0.23 & 0.18 \\
\hline Ileum & 1.0 & 1.0 & 1.3 & 1.3 & 0.11 & 0.02 & 0.77 & 0.95 \\
\hline Pancreas & 1.6 & 1.9 & 1.9 & 2.1 & 0.10 & 0.02 & 0.01 & 0.89 \\
\hline Liver & 21.6 & 21.7 & 23.1 & 22.3 & 0.48 & 0.03 & 0.52 & 0.33 \\
\hline
\end{tabular}

${ }^{1}$ potato protein concentrate; ${ }^{2}$ cellulose; ${ }^{3}$ potato fibre preparation

Viscosity of digesta ranged from 2.25 to $3.78 \mathrm{mPa} \cdot \mathrm{s}$ and did not depend on the dietary components (not shown).

\section{Morphometry of the small intestine (Experiment 2)}

All measured parameters were affected either by protein or by fibre but course and magnitude of these effects were inconsistent and differed among the segments (Table 9). In most cases (except tunica muscularis in jejunum and ileum, and tunica mucosa in duodenum) interactive effects of both factors were found.

Table 9. Effects of supplementary protein (P) and fibre (F) on morphology of small intestine, $\mu \mathrm{m}$ (Experiment 2)

\begin{tabular}{|c|c|c|c|c|c|c|c|c|}
\hline \multirow{2}{*}{ Item } & \multicolumn{2}{|c|}{ Casein } & \multicolumn{2}{|c|}{$\mathrm{PPC}^{1}$} & \multirow{2}{*}{ SEM } & \multicolumn{3}{|c|}{ Significance } \\
\hline & $\mathrm{CEL}^{2}$ & $\mathrm{PF}^{3}$ & CEL & PF & & $\mathrm{P}$ & $\mathrm{F}$ & $\mathrm{P} \times \mathrm{F}$ \\
\hline \multicolumn{9}{|c|}{ Duodenum } \\
\hline Villus high & 340 & 292 & 324 & 318 & 9.2 & 0.59 & 0.00 & 0.02 \\
\hline Crypt depth & 231 & 277 & 257 & 258 & 9.0 & 0.67 & 0.01 & 0.01 \\
\hline Tunica mucosa & 614 & 594 & 648 & 621 & 14.3 & 0.03 & 0.10 & 0.82 \\
\hline Tunica muscularis & 488 & 470 & 466 & 494 & 13.5 & 0.97 & 0.72 & 0.09 \\
\hline \multicolumn{9}{|c|}{ Jejunum } \\
\hline Villus high & 391 & 462 & 408 & 342 & 11.5 & 0.00 & 0.83 & 0.00 \\
\hline Crypt depth & 237 & 263 & 275 & 262 & 7.4 & 0.01 & 0.37 & 0.01 \\
\hline Tunica mucosa & 684 & 769 & 740 & 643 & 15.3 & 0.02 & 0.68 & 0.00 \\
\hline Tunica muscularis & 306 & 384 & 358 & 415 & 10.0 & 0.00 & 0.00 & 0.28 \\
\hline \multicolumn{9}{|c|}{ Ileum } \\
\hline Villus high & 315 & 371 & 359 & 330 & 8.6 & 0.89 & 0.11 & 0.00 \\
\hline Crypt depth & 226 & 284 & 263 & 236 & 8.5 & 0.49 & 0.06 & 0.00 \\
\hline Tunica mucosa & 574 & 699 & 662 & 617 & 14.2 & 0.82 & 0.01 & 0.00 \\
\hline Tunica muscularis & 515 & 555 & 551 & 565 & 17.8 & 0.20 & 0.13 & 0.48 \\
\hline
\end{tabular}

${ }^{1}$ potato protein concentrate $;{ }^{2}$ cellulose $;{ }^{3}$ potato fibre preparation

The effect of PF on villi length was in all segments greater when it was fed with casein than with potato protein, and differed among the segments. Supplementing 
casein diet with PF decreased length of villi in duodenum but increased in jejunum and ileum, as compared with CEL. When fed with potato protein, PF had very small effect on villi length in duodenum and ileum but decreased it considerably in jejunum.

Crypts depth was also more affected by PF when it was fed with casein than with potato protein. In all segments crypt depth on casein diets was greater on PF than on CEL whereas on potato protein diets it did not differ in duodenum and jejunum being slightly smaller in ileum.

Thickness of mucosa in duodenum was greater on potato protein than on casein diets and tended $(\mathrm{P}=0.10)$ to be slightly lower on $\mathrm{PF}$. In jejunum and ileum mucosa was substantially increased by PF when fed with casein and decreased when fed with potato protein.

Tunica muscularis in duodenum and ileum depended neither on dietary protein nor fibre while in jejunum it was increased both by potato protein and PF being the smallest on casein supplemented with CEL and the greatest on potato protein supplemented with PF (306 vs $415 \mu \mathrm{m}$, respectively).

\section{Concentration of protein and lipid metabolites in blood (Experiment 2)}

Total protein concentration did not differ among pigs fed on experimental diets while urea concentration was higher in animals fed on potato protein (Table 10). Feeding both potato protein and PF increased concentration of triglycerides, which was the lowest on casein diet supplemented with CEL and the highest on potato protein diet supplemented with $P F(0.41 \mathrm{vs} 0.58 \mathrm{mmol} / 1$, respectively). Total cholesterol was not affected by protein but was increased by PF. No interactive effects of the two factors were observed.

Table 10. Effects of supplementary protein $(\mathrm{P})$ and fibre $(\mathrm{F})$ on blood parameters (Experiment 2)

\begin{tabular}{|c|c|c|c|c|c|c|c|c|}
\hline \multirow{2}{*}{ Item } & \multicolumn{2}{|c|}{ Casein } & \multicolumn{2}{|c|}{$\mathrm{PPC}^{1}$} & \multirow{2}{*}{ SEM } & \multicolumn{3}{|c|}{ Significance } \\
\hline & $\mathrm{CEL}^{2}$ & $\mathrm{PF}^{3}$ & CEL & PF & & $\mathrm{P}$ & $\mathrm{F}$ & $\mathrm{P} \times \mathrm{F}$ \\
\hline 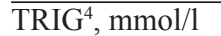 & 0.41 & 0.46 & 0.47 & 0.58 & 0.026 & 0.00 & 0.00 & 0.32 \\
\hline $\mathrm{TP}^{5}, \mathrm{~g} / \mathrm{l}$ & 65.42 & 65.07 & 66.14 & 65.25 & 1.538 & 0.77 & 0.69 & 0.86 \\
\hline Urea, $\mathrm{mmol} / \mathrm{l}$ & 2.28 & 2.32 & 2.86 & 3.03 & 0.173 & 0.00 & 0.55 & 0.71 \\
\hline $\mathrm{CHOL}^{6}, \mathrm{mmol} / 1$ & 1.98 & 2.32 & 2.13 & 2.38 & 0.119 & 0.38 & 0.01 & 0.69 \\
\hline
\end{tabular}

${ }^{1}$ potato protein concentrate; ${ }^{2}$ cellulose; ${ }^{3}$ potato fibre preparation; ${ }^{4}$ triglycerides; ${ }^{5}$ total protein; ${ }^{6}$ cholesterol

\section{DISCUSSION}

Nutritional value of potato protein concentrate for young pigs. Protein content and amino acid composition of the PPC used in our experiments was within range 
given by Rademacher et al. (1999), Sauvant et al. (2004) and Pastuszewska et al. (2009) which confirms the great potential of this feed as a well balanced source of essential AA. On the contrary, the availability of protein and AA determined as their AID, was in our study considerably lower than values published by Rademacher et al. (1999) and Sauvant et al. (2004). According to these authors, PPC is digested in the small intestine with similar or even greater efficiency than highly digestible proteins of plant and animal origin while in our experiment it was digested to a far less extent than CAS. The low AID of AA and protein of PPC found in our study is, however, in agreement with the results of experiments performed with rats (Morita, 1998; Taciak, 2006) which also indicate for some resistance of PPC to enzymatic digestion.

The lack of consistency of the reported AID values may be explained either by likely differences in the technology of the concentrate production or by variable contents of antinutritional factors such as protease inhibitors or solanidine glycoalkaloids. In the study of Urbaityte et al. (2009) on piglets, the standardized ileal digestibility of indispensable amino acids of potato protein concentrates originated from two manufacturers, differed for about 5 units. The experimental data relating ileal digestibility of PPC to technological treatment or to the contents of antinutritional factors are, however, lacking. Glycoalkaloids seem to have a smaller impact as the recent study of Tuśnio et al. (submitted to publication) performed on chickens, did not show any negative effect of high concentration of glycoalkaloids on AID of dietary protein. The effects of trypsin inhibiting activity cannot be, however, excluded.

The apparent controversies on the ileal digestibility of protein and amino acids of PPC indicate for a need of a more detailed study of factors responsible for its nutritional value for pigs.

In contrast to great difference between ileal protein digestibility of PPC and CAS, total protein digestibility of cereal diets supplemented with casein was only slightly greater than of supplemented with potato protein. The apparent biological value (nitrogen retained/nitrogen absorbed) of dietary protein was high and did not differ which reflected proper supplementation with crystalline amino acids.

According to Kerr et al. (1998) the acceptable dietary levels of PPC for piglets depend on the content of solanidine glycoalkaloids which depress feed intake and growth performance due to their bitter off-flavour. The authors postulate that the $8 \%$ level of a low-glycoalkaloid $(156 \mathrm{mg} / \mathrm{kg}$ ) potato protein may potentially be the maximum addition for weanling piglets. The results of the Experiment 2 of our study show that older piglets (initial body weight about $15 \mathrm{~kg}$ ) tolerate much higher $(17.5 \%)$ level of PPC with greater GA concentration $(677 \mathrm{mg} / \mathrm{kg})$. The animals fed on cereal diet containing PPC as the only protein source had similar feed intake and growth rate, and even slightly better feed conversion than piglets 
fed on casein-supplemented diet. Absence of negative effect of potato protein on growth performance of older pigs (initial body weight $22 \mathrm{~kg}$ ) was found also by Spielmann et al. (2009) who fed diets containing casein, fish meal or potato protein at the level increased from 15 to $19.4 \%$ during 21 days of experiment. Potato protein appeared to be a good substitute of fish meal when fed at $6 \%$ level to piglets of the initial body weight $7.5 \mathrm{~kg}$ (Sardi et al., 2005) and when fed at $8 \%$ level with faba beans as the protein source for growing-finishing pigs (Sundrum et al., 2000). In the reported studies the concentration of glycoalkaloids in PPC was not given.

Feeding potato protein produced changes in the morphology and morphometry of digestive tract. Relative weights of liver and pancreas were slightly greater in pigs fed on PPC than on CAS diets which may indicate for a greater metabolic activity of these organs. The enlargement of liver was found also by Spielmann et al. (2009) in pigs fed similar amounts of PPC while progressive hypertrophy of liver and pancreas was observed in chickens fed increasing amounts of PPC (Tuśnio et al., submitted to publication). Changes of liver weight are considered as the manifestation of hepatoxic effects of glycoalkaloids (Friedman et al., 1996) while hypertrophy of pancreas may reflect stimulatory effect of trypsin inhibiting activity on pancreatic secretion. Such effects are found when protease inhibitors present in soyabean are fed to rats and chickens but not to pigs. Nothing is known, however, about the response of pancreas of very young pigs to the protease inhibiting activity of potato origin.

The effect of protein on the morphometry of the small intestine was found in jejunum and depended on the type of accompanying fibre. On general, PPC fed with CEL caused the increase of villi heigh, crypt depth and width of mucosa and muscularis layers but when fed with PF, it decreased or did not affect these parameters as compared with CAS.

The absence of apparent negative impact of PPC fed with CEL shows that solanidine glycoalkaloids at the dietary level $118.5 \mathrm{mg} / \mathrm{kg}$ do not damage the structure of intestinal epithelium in pigs. It cannot be, however, excluded, that greater amounts of these antinutrients may impair the epithelium, as it was found in chicken (Tuśnio et al., submitted to publication). On the other hand, the interactive effects of protein and type of fibre point to the significance of the composition of the whole diet and not only single dietary components, for maintenance of this structure which is an important component of gut health and functionality.

In our study PPC significantly influenced lipid metabolism. Fat digestibility was considerably greater on diets containing PPC than CAS, which cannot be explained by eventually greater digestibility of trace amounts of fat provided by these products but by better absorption of the total dietary lipids. The greater absorption was accompanied by higher blood levels of triglycerides in pigs fed on 
PPC than on CAS while the total cholesterol concentration did not differ. These findings are contradictory to the hypolipidaemic effect of potato protein observed in rats (De Schrijver, 1990) and its hypocholesterolaemic but not hypolipidaemic, effect found in pigs (Spielmann et al., 2009). Pigs and not rats, are considered as a better model of lipid metabolism when related to humans.

Nutritional and physiological effects of potato fibre. Dietary fibre is generally considered as an antinutritive component for young monogastric animals because of its negative influences on digestion. However, due to its interactions with microflora and mucosa it has also an important role in the control of 'gut health' and may either protect from or enhance enteric infections in very young animals depending on its characteristics and origin (Montagne et al., 2003).

In our study performed on young pigs adapted to post-weaning feeds substitution of PF for CEL did not depress growth parameters and even tended to improve efficiency of feed utilization. This effect can be ascribed to a greater metabolizable energy value of diets containing PF, resulting from higher digestibility of fat, fibre and NFE. Digestibility of the mixture of potato protein and casein both in the small intestine and in the whole gastrointestinal tract did not depend on the type of fibre but AID of several amino acids was lower on PF than on CEL.

The negative effects of native fibre on ileal protein digestibility are related mostly to binding protein to or encapsulating by fibre fractions. The effect of fibre added to the diet, as was the case in our study, depends on its physicochemical properties such as water-solubility, water-binding and viscosity which influence viscosity, dry matter content and transit time of digesta (Buraczewska, 2001). Cellulose is a water-insoluble fibre which does not affect ileal digestibility of protein and amino acids even when added up to the $13 \%$ level (Li et al., 1994) while inclusion of the soluble fibre (pectin) generally increases viscosity of digesta and decreases ileal digestibility (Mosenthin et al., 1993). Potato fibre is composed of insoluble (cellulose) and soluble (hemicellulose, pectins) fractions but, as found in Experiment 2, it does not increase viscosity nor depress ileal protein digestibility, as compared with CEL. Similar results were obtained by Antuszewicz et al. (2005b) who did not find significant differences in ileal digestibility of protein of casein-wheat diets supplemented either with $5 \%$ of PF, cellulose or pectin.

The AID of glycine, serine and threonine were lower on diet containing PF than CEL. This may indicate for the stimulating effect of PF on endogenous secretion, particularly of mucins which contain relatively high proportions of these amino acids (Li et al., 1994).

In spite of similar total protein digestibility, utilization of protein absorbed tended to be lower in animals fed on PF. These findings may indicate that PF does not stimulate fermentation and bacterial protein synthesis in the large intestine which is, however, inconsistent with greater fermentability of PF than CEL found both in older pigs (Jorgensen, 1997) and in rats (Antuszewicz, 2006). The possible 
explanation may be the younger age of pigs used in our experiment as the intensity of fermentation augments with age and weight of pigs.

Potato fibre had substantial delaying effect on the passage rate of digesta in the whole gastrointestinal tract. It contrasts with generally observed acceleration of intestinal transit by soluble fibre as opposed to insoluble fibre (Montagne et al., 2003).

The results of Experiment 2 showed that the effects of fibre on epithelial morphology differ among the segments and in all segments depend on type of protein. When PF was added to casein diet, villi height was smaller than on CEL in duodenum and greater in jejunum and ileum whereas when supplemented to diet containing potato protein it did not affect villi height in duodenum and decreased it in jejunum and ileum. Crypt depth was increased or tended to be increased by $\mathrm{PF}$ added to casein diet while it was not affected or affected to a small extent when added to diet with potato protein. The interactive effects of fibre and protein were also found for the width of mucosa, and only tunica muscularis width was increased by PF both on casein and potato protein. In view of these discrepancies it is very difficult to draw general conclusion on the comparative effects of CEL and $\mathrm{PF}$ and this finding is consistent with the diversity of observations made by other authors using different amounts and types of fibre, as reported by Montagne et al. (2003). The two-factorial design of our experiment evidenced the interrelationship of protein and fibre in shaping morphology of the small intestine.

Contrary to the expectations, PF did not reveal beneficial health effects on lipid metabolism since fat digestibility and blood levels of triglycerides and total cholesterol were greater in pigs fed on PF than on CEL. These findings disagree with results obtained previously in rats by Lærke et al. (2007) and Pastuszewska et al. (2010) who found that substitution of PF or its fractions for CEL decreased triglycerides level and did not affect total cholesterol. The hypercholestrolaemic effect of PF is difficult to explain in view of the similar and low viscosity of digesta which is one of factors affecting resorption of bile acids and synthesis of cholesterol.

\section{CONCLUSIONS}

It may be concluded that potato protein concentrate with relatively low glycoalkaloid concentration and trypsin inhibiting activity is well utilized by young pigs when fed at the level considerably higher than recommended $5 \%$, and does not provoke apparent negative consequences. The effects of higher levels of glycoalkaloids and trypsin inhibitor activity remain to be established. Potato fibre generally does not depress nutrients digestibility and nutritive value of the diet but does not reveal evident health promoting effects. 


\section{REFERENCES}

Antuszewicz A., 2006. Nutritional value and physiological activity of dietary fibre preparation from fruits and vegetables - studies on rats and piglets (in Polish). PhD Thesis, Agricultural University in Warsaw - SGGW. Warsaw

Antuszewicz A., Święch E., Żebrowska T., 2005b. Glucose, insulin and cholesterol levels in blood of growing pigs given diets with various sources of fibre. J. Anim. Feed Sci. 14, Suppl. 1, 325328

Antuszewicz A., Taciak M., Żebrowska T., 2005a. The schort-chain fatty acids content in the caecal digesta of rats fed diets with various sources of fibre. J. Anim. Feed Sci. 14, Suppl. 1, 521-524

Buraczewska L., 2001. Fibre components negatively affect ileal protein digestibility in pigs. J. Anim. Feed Sci. 10, Suppl. 1, 139-152

Buraczewska L., Buraczewski S., 1984. A note on determination of methionine and tryptophan. In: Proceedings of 6th International Symposium on Amino Acids. Serock (Poland). Polish Scientific Publishers. Warszawa, pp. 47-50

Buraczewska L., Wasilewko J., Fandrejewski H., Żebrowska T., Han I.K., 1999. Formulation of pig diets according to ileal digestible amino acid content. Livest. Prod. Sci. 59, 13-24

De Schrijver R., 1990. Cholesterol metabolism in mature and immature rats fed animal and plant protein. J. Nutr. 120, 1624-1632

Friedman M., Henika P.R., Mackey B.E., 1996. Feeding potato, tomato and eggplant alkaloids affects food consumption and body and liver weights in mice. J. Nutr. 126, 989-999

Jakob S., Mosenthin R., Sauer W.C., 1999. Carbohydrates and exocrine pancreatic secretion in pigs. In: S.G. Pierzynowski, R. Zabielski (Editors). Biology of the Pancreas in Growing Animals. Elsevier, Amsterdam, pp. 361-370

Jorgensen H., 1997. Energy utilization of diets with different sources of dietary fibre in growing pigs. In: K. McCracen, E.F. Unsworth, A.R.G. Wylie (Editors). Proceedings of the $14^{\text {th }}$ Symposium on Energy Metabolism, Energy Metabolism of Farm Animals. Newcastle, pp. 367-370

Kerr C.A., Goodband R.D., Smith J.W., Musser R.E., Bergstrom J.R., Nessmith W.B., Tokach M.D., Nelssen J.L., 1998. Evaluation of potato proteins on the growth performance of early-weaned pigs. J. Anim. Sci. 76, 3024-3033

Lærke H.N., Meyer A.S., Kaack K.V., Larsen T., 2007. Soluble fiber extracted from potato pulp is highly fermentable but has no effect on risk markers of diabetes and cardiovascular disease in Goto-Kakizaki rats. Nutr. Res. 27, 152-160

Lee S.S., Liener I.E., Desborough S., 1985. Comparative effects of feeding a protease inhibitor enriched potato protein concentrate and soy flour to rats. Plant Food. Hum. Nutr. 35, 9-19

Li S., Sauer W.C., Huang S.X., Mosenthin R., 1994. Effect of cellulase supplementation to barleybased diet on the digestibility of energy, $\beta$-glucans, crude protein and amino acids in earlyweaned pigs. In: W.B. Souffrant, H. Hagemeister (Editors). Proceedings of the $6^{\text {th }}$ International Symposium on Digestive Physiology in Pigs. Bad Doberan (Germany), pp. 357-359

Montagne L., Pluske J.R., Hampson D.J., 2003. A review of interactions between dietary fibre and the intestinal mucosa, and their consequences on digestive health in young non-ruminant animals. Anim. Feed Sci. Tech. 108, 95-117

Morita T., Kasaoka S., Oh-hashi A., Ikai M., Numasaki Y., Kiriyama S., 1998. Resistant proteins alter cecal short-chain fatty acid profiles in rats fed high amylose cornstarch. J. Nutr. 128, 1156-1164

Mosenthin R., Sauer W.C., Ahrens F., 1994. Dietary pectin's effect on ileal and fecal amino acid digestibility and exocrine pancreatic secretions in growing pigs. J. Nutr. 124, 1222-1229 
Pastuszewska B., Taciak M., Tuśnio A., Misztal T., Ochtabińska A., 2010. Physiological effects of long-term feeding diets supplemented with potato fibre or cellulose to adult rats. Arch. Anim. Nutr. 64, 155-169

Pastuszewska B., Tuśnio A., Taciak M., Mazurczyk W., 2009. Variability in the composition of potato protein concentrate produced in different starch factories-A preliminary survey. Anim. Feed Sci. Tech. 154, 260-264

Rademacher M., Sauer W., Jansman A., 1999. Standardized Ileal Digestibility of Amino Acids in Pigs. Degussa-Hüls. The New System

Refstie S., Tiekstra H.A.J., 2003. Potato protein concentrate with low content of solanidine glycoalkaloids in diets for Atlantic salmon (Salmo salar). Aquaculture 216, 283-298

Sardi L., Paganelli R., Parisini P., Simioli M., Martelli G., 2005. The replacement of fishmeal by plant proteins in piglet production. Ital. J. Anim. Sci. 4, Suppl. 2, 449-451

Sauvant D., Perez J.-M., Tran G., 2004. Tables of Composition and Nutritional Value of Feed Materials. Wageningen Academic Publishers (The Netherlands)

Serena A., Bach Knudsen K.E., 2007. Chemical and physicochemical characterization of coproducts from the vegetable foods and agro industries. Anim. Feed Sci. Tech. 139, 109-124

Spielmann J., Kluge H., Stangl G.I., Eder K., 2009. Hypolipidaemic effects of potato protein and fish protein in pigs. J. Anim. Physiol. Anim. Nutr. 93, 400-409

Taciak M., 2006. Nutritional value of proteins of plant and animal origin and their effects on selected gut functions in the rat (in Polish). PhD. Thesis, The Kielanowski Institute of Animal Physiology and Nutrition. Jabłonna (Poland)

Tuśnio A., Pastuszewska B., Taciak M., Mieczkowska A., Smulikowska S., 2011. Potato protein concentrate as a protein supplement in chicken diets - effects of solanidine glycoalkaloids and trypsin inhibitor on growth performance and on gut morphology and functions. Submitted to publication in J. Anim. Feed Sci.

Urbaityte R., Mosenthin R., Eklund M., Piepho H.P., Sauer N., Rademacher M., 2009. Standardised ileal crude protein and amino acid digestibilities in protein supplements for piglets. Arch. Anim. Nutr. 63, 5, 356-378

van Leeuwen P., van Kleef D., van Kempen G.J.M., Huisman J., Verstegen M.W.A., 1991. The postvalve T-caecum cannulation technique in pigs applicated to determine the digestibility of amino acids in maize, groundnut and sun flower meal. J. Anim. Physiol. Anim. Nutr. 65, 183-193 